\title{
The New Silk Roads
}

\author{
Peter Frankopan (2018), The New Silk Roads, London: Bloomsbury Publishing,
} 253pp

ISBN: 9781526607423 (hardback)

\section{Katja Laug, The University of Warwick, Coventry}

Peter Frankopan follows his 2015 Bloomsbury publication The Silk Roads: A New History of the World with an illuminating account of the present and projected future of global economic and power structures that shifts the centre of attention away from the Western-centric narrative and towards the East and the re-emergence of economic power structures, particularly in Asia.

The New Silk Roads sets out to demonstrate that 'the decisions being made in today's world that really matter are not being made in Paris, London, Berlin or Rome (...) but in Beijing and Moscow, in Tehran and Riyadh, in Delhi and Islamabad, in Kabul and in Taliban-controlled areas of Afghanistan, in Ankara, Damascus and Jerusalem' (p. 7). What follows Frankopan's declaration is an insightful and wide-ranging analysis of global power structures and economics that is decidedly missing from mainstream Western discourses and media landscapes. The book traces the rising power in the East as a consequence of the 'demands and needs for resources, goods, services and skills' in the developed economies of the Global North, which has led to a 'crisis of confidence' in Europe and the US. Yet, Frankopan argues, the 'sun rising in the east does not mean that it is setting on the west. Not yet, at least' (p. 43).

Frankopan traces how Europe appears unable to cope with tensions arising from migration and the arrival of displaced peoples from Africa and the Middle East, from member states' inherent inability to see eye to eye, from Britain's tendency to sentimentalise the Empire, and from a lack of coherent strategies for international cooperation and to secure a place at the future tables of power. On the other, countries along the Silk Roads, Frankopan suggests, seek common interests and denominators and foster mutually beneficial investment and collaboration practices and China is leading the way. 'The Silk Roads are an integral part not only of China's economic and foreign policy,' Frankopan argues, 'they are an integral part of how China sees the world - and how it is preparing for the future' (p. 148). 

Like other critics, philosophers and thinkers, such as Pankaj Mishra or Noam Chomsky, Frankopan views the rise of the far-right and fascism across the global North as a symptom of a dying Empire and shifting powers from West to East, and considers the 'triumph of liberal democracy (...) on hold, if not over' (p. 243). Frankopan is not blind to the inherent flaws of 'liberal western democracy', and his often-scathing criticism of particularly US foreign and domestic policies are justified both by the present and by historic records. Yet, where Frankopan is clear-sighted in the failings of the Western powerhouses on these matters, The New Silk Roads is less so on other issues, particularly on the human cost of the current and projected shifting economic and political power structures. The analysis of the recent bilateral relationships between China and several African countries mentions, but fails to examine, the inherently problematic nature of Chinese investments across Africa. Nor does his mention of record numbers of African students studying in China consider the rampant anti-African racism there that has recently received international attention and continues to play a role in how business is conducted between African nations and China. The mention of the tentative changes in the relationship between Saudi Arabia and Israel does not account for potential repercussions for or from Palestine, and the mention of the human rights crisis suffered by the Uighurs in western China, while not absent, does not factor into Frankopan's perspective on China's return to global power.

In his discussion on India's economic developments and future in the Belt and Road Initiative, Frankopan succinctly points out the growing middle class in the country, highlighting a growing number of households 'with disposable incomes of more than $\$ 10,000$ a year' (p. 32) rising from 2 million to 50 million in less than 25 years. While this data is significant, it does not account for the rise in overall population in the same time, nor does it consider the persistently high rates of abject poverty that ravages especially rural communities across the nation and has recently been compounded by droughts. Wealth in India, as elsewhere, is concentrated in urban areas, and these urban areas are over-populated, unequal and unsustainable.

Frankopan also fails to address the rise of Hindu-fascism that is currently descending with a vengeance on Muslim communities and liberation movements across the country. This has recently sparked a resistance movement that has been absent from Indian politics for decades and has generated international support as well as repressive violence in India itself. Kashmir, another region implicated in the power struggles in the region, barely makes an appearance in The New Silk Roads, despite the vital role it plays in securing access to water for both India and Pakistan - the 
Kashmiris being another people relegated to the side-lines of the analysis of global and regional politics.

'A new world is emerging in Asia,' Frankopan predicts, 'but it is not a free one' (p. 81). Throughout The New Silk Roads, the author hints at the potential for unfreedom and human rights violations in those nations collaborating to establish the new Silk Roads, but fails to factor into his analysis the human cost or the potential for peoples to resist and change the paths of politics. Where Silk Road nations such as China, India, Iran, Russia, Turkey and many others utilise increasingly repressive measures to control their populations, these measures are a reaction to increasing resistance against the political elites that place growth before life. Omitting these resistance movements from an analysis of shifting power structures appears at times myopic, at times fatalistic.

Scientists and economists agree that exponential growth is not a sustainable economic model, neither for the environment nor for human life. Western liberal democracy and economic dominance has wreaked havoc on the planet and on its peoples, especially in the Global South. To date, any redress for the ecological damage proposed in a series of 'Green New Deals' is contingent on the continued exploitation of the peoples, minerals, natural resources and cheap and precarious labour of the Global South. Frankopan's projections see a linear shift in global power based on the continued extraction of wealth and labour from countries rich in natural and human resources. This shift may come about through investments and uneasy political alliances, rather than military might and force, yet who will be the beneficiaries of these new trade deals and who will pay the price for the economic growth required to complete this shift?

The New Silk Roads is an important book that seeks to provide a more complete understanding of economic patterns and resulting political power on a truly global scale. It may not be possible to predict the human aspect of politics, the potential for resistance and effecting change for the wider population, but it is something to keep in mind when reading Frankopan's exceptionally insightful book on global economics and politics.

\section{Shayla Rance, Monash University, Australia}

Peter Frankopan's The New Silk Roads builds upon his earlier publication, Silk Roads (2015). This later volume provides a concise, reader-friendly insight into the shift of 
the centre of the political and economic spheres of the world. In Silk Roads, Frankopan likens the global order as parallel to the silk roads that were historically at the centre of trade and culture centuries ago. The original publication (2015) talked about the international political economy at that specific point in time, which is of interest as it encapsulates the complexities of a juncture in history. However, in The New Silk Roads, Frankopan talks about a different juncture, looking at current issues, and the volumes, when read together, illustrate exactly how rapidly the world has changed between the two publications. Although the overarching claims between the works generally remain the same, in The New Silk Roads, Frankopan makes an important distinction: that all roads lead to Beijing, and this would not have happened without increasing Chinese bilateral investment in the region. Frankopan centres his take on the current international political economy as one that could not function in the same without Chinese policy. As a result of this, much of the book rightly focuses on President Xi's 'One Belt, One Road' initiative and the development it has meant for nations along the Silk Road and further afield in peripheral regions such as Africa or South Asia.

\section{Can 'One Belt, One Road' be considered sustainable?}

What Frankopan touches upon in his discussion is the fact that China's offshore investment is largely unprecedented. The sheer amount of bilateral investment between China and developing nations has previously been unheard of, and the potential complications that have arisen from this new venture are not lost on Frankopan. The author quotes Xi Jinping in his discussion of the Northern Powerhouse project, which proposed a boost to the economy of Northern England, as demonstrative of the philanthropic interest of nations in new, large-scale infrastructure projects. However, President Xi's argument that this sort of extensive investment is commonplace internationally is absurd. Frankopan points out how the Northern Powerhouse project is insignificantly sized in comparison. The lack of accurate statements from political leaders, not only Xi Jinping, sets the tone for Frankopan's outlook on the topic 'is Xi's “One Belt, One Road” and ensuing investment sustainable?' Will developing nations be able to pay back loans made, or - as we have already started to see - will countries be forced to forfeit assets under economic duress to Chinese investors at bargain rates? The New Silk Roads takes a somewhat realist outlook on the current political landscape and does not shy away from pointing out some of the hypocrisies that continue to plague not only investment in developing countries, but also a melting pot of policy issues and current affairs. The book does a 
Reinvention: an International Journal of Undergraduate Research 13:1 (2020) fantastic job of simplifying the complexities of the international political economy into something more accessible, and ultimately more concerning, for the nonspecialist reader.

What does this mean for the current international political economy?

Politically, Frankopan is pragmatic in his belief that 'the ability to prepare for the future looks questionable'. He says this while arguing that a true neoliberal world order does not exist and that regionalism (especially Eurocentrism) remains.

Frankopan argues that many developed nations are unwilling to fully commit to a truly interconnected global order (if in doubt, think of Brexit, or Trump's antiimmigration policies), which has forced many crucial negotiations to exist outside of traditional neoliberal institutions, causing huge problems for their legitimacy. Having bilateral discussions means that international cooperation, at least in the author's eyes, is at an all-time low. Thus, it should not be a surprise that the investment in the developing world is now coming from the East instead of the West, or, as other academics in the field describe it, the shift as unipolar to bipolar global order. This shift, however accurate it may be, does not address the impact of what the global climate crisis will have on nations that are more densely populated without the mature urban planning and infrastructure of core nations. What does it mean in the long term if the centre of the economic and political world is Beijing, if air and water pollutants make it an undesirable, or uninhabitable place to live? What impact will this have on the ongoing infrastructural development plans of Chinese developers, when global temperatures are rising? If these are some of the more pressing questions you hold as a reader, then The New Silk Roads may not be the book for you.

Frankopan's notes are extensive, spanning 45 pages of in-depth and varied sources. Many of the sources mentioned in these notes are translated from other languages or come left-field to what many other academics in the field are basing their research on. This is interesting as it allows The New Silk Roads to have a slightly different take on the topic, but it makes it difficult to track the authors' thought process.

The crux of my issue with the publication is that it is not comprehensive of the impact of the climate crisis on the international political economy. While being a captivatingly fresh take on the current global order, it is not a substitute for more thoroughly researched academic texts. However, it does make for an enjoyable read and is perfect for anyone wanting to get acquainted with the topic, or as an addition to more scholarly research. 
To cite this paper please use the following details: Laug, K OR Rance, S. (2020), Frankopan, Peter. (2018), 'The New Silk Roads', Reinvention: an International Journal of Undergraduate Research, Volume 13, Issue 1, https://reinventionjournal.org/article/view/617/. Date accessed [insert date]. If you cite this article or use it in any teaching or other related activities please let us know by e-mailing us at Reinventionjournal@warwick.ac.uk. 